\title{
Antioxidant Activity of Indian Medicinal Rice (Oryza Sativa L.) cv. Njavara
}

\author{
Reshmi. R*, Nandini P.V
}

*(Corresponding author) Reshmi.R, Kumbalathu Veedu, PGRA J-16, Sasthamkulam ane, Vallakadavu, P.O.,

Thiruvananthapuram, India

Dr. Nandini P.V., Rtd. Professor, Department of Home Science, College of Agriculture, Vellayani, Thiruvananthapuram, India

\begin{abstract}
A study was conducted to find out the antioxidant activity of medicinal rice (Oryza sativa L.) $\mathrm{cv}$. Njavara. Two eco types of Njavara rice Njavara black $(N B)$ and Njavara yellow (NY) were procured from RRS, Moncompu and one eco type of Hraswa was obtained from ARS, Mannuthy. Hraswa was treated as the control.

Diphenyl picryl hydrazyl (DPPH) radical scavenging activity, hydroxyl radical scavenging activity, superoxide anion radical scavenging activity, reducing power assay, total antioxidant activity, total phenols, zinc and selenium (Se) were estimated.

The results of the antioxidant properties revealed that for $D P P H$ scavenging activity and hydroxyl radical activity $N Y$ had highest antioxidant activity. For superoxide radical scavenging activity, NB had the highest activity.

Present investigation showed that as the concentration increased, the reducing power of all the rice varieties increased and the highest reducing power was shown by NB.
\end{abstract}

NY had shown the highest total antioxidant activity.

Present study revealed that among the three rice varieties $N B$ had the highest total phenol content.

$Z n$ content was slightly higher in NY than NB. The present study revealed that control variety Hraswa had the highest Se content.

Keywords- Njavara, Hraswa, Rice, Varieties, Antioxidants.

\section{INTRODUCTION}

Plants and their products have been used for many years for human health. There are still many plants which have various medicinal values but still not explored and used. Plants contain many novel compounds with medicinal values which need scientific exploration. The free radicals are produced in aerobic cells due to consumption of oxygen in cell growth (Barros et al., 2007; Singh et al., 2007).

Free radicals cause decrease in membrane fluidity, loss of enzyme receptor activity and damage to membrane protein leading to death ( $\mathrm{Li}$ et al., 2007). These free radicals are involved in different disorders like ageing, cancer, cardiovascular disease, diabetes, rheumatoid arthritis, epilepsy \& degradation of essential fatty acids (Barros et al., 2007; Singh et al., 2007).

Antioxidant helps in treatment of above disorders. Antioxidants may be defined as substances whose presence in relatively low concentrations significantly inhibits the rate of oxidation of the target within the biological systems (Lai et al., 2009). According to Geethakutty et al. (2004) Njavara is a good antioxidant.

No other medicinal rice is used in the world as widely as Njavara in Ayurveda. Its importance as a health food offers opportunity to establish niche global market.

'Ashtanga Hridaya' describes two types of Njavara- black and white. According to the farmers and healers it is a precious gift from God to the "God's own Country" Kerala. Njavara rice, with a distinct gene pool and medicinal properties, can be exploited as nutraceutical rice (Deepa et al., 2009; Sulochana and Bakiyalakshmi, 2011).

Studies related to antioxidant activity in Njavara rice are rather limited. So the present study is an attempt to investigate the above said indicators in comparison with a short duration non-medicinal variety, Hraswa.

\section{MATERIALS AND METHODS}

Njavara rice varieties [Njavara black (NB) and Njavara yellow (NY)] were collected from Rice Research Station of Kerala Agriculture University, Moncompu and Hraswa was collected from Agriculture Research Station, Mannuthy, Thrissur.

The following methods were used for the analysis of antioxidant activity:

$$
\begin{array}{llll}
\text { a. } & \text { Diphenyl Picryl Hydrazyl (DPPH) radical } \\
\text { scavenging activity }
\end{array}
$$

Free radical scavenging activity of sample to characterize antioxidant activity was estimated as suggested by Blois (1958). Different amount of the methanolic extract of the 
sample was taken and DPPH $(0.1 \mathrm{mM}$ dissolved in methanol) was mixed together and the reaction mixture was left in dark room for 20 minutes. The absorbance was measured at $517 \mathrm{~nm}$ against the blank prepared by mixing DPPH and methanol. The antioxidant activity was expressed in terms of per cent inhibition of DPPH free radicals using the following equation:

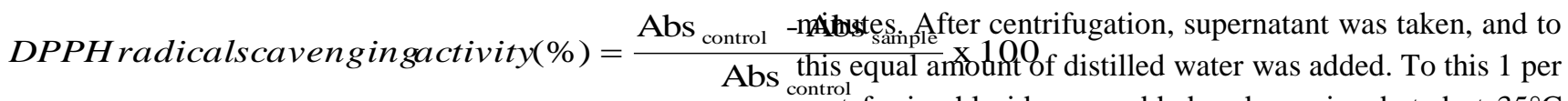
cent ferric chloride was added and was incubated at $35^{\circ} \mathrm{C}$ Where, $\mathrm{Abs}_{\text {control }}=$ absorbance of DPPH solution (blank) and $\mathrm{Abs}$ sample $=$ absorbance of sample. The $\mathrm{IC}_{50}$ of each sample (concentration in $\mu \mathrm{g} / \mathrm{ml}$ required to inhibit DPPH radical formation by 50 per cent) has also been calculated.

b. Hydroxyl radical scavenging activity

In order to assess the hydroxyl free radical scavenging activity of the methanolic extracts of the rice samples, the deoxyribose method was used, as described by Halliwell et al. (1987), with some slight modifications. The reaction mixture contained phosphate buffer (20 mM, pH 7.4), 60 $\mathrm{mM}$ deoxyribose, $10 \mathrm{mM}$ Hydrogen peroxide, $1 \mathrm{mM}$ ferric chloride, $1.04 \mathrm{mM}$ EDTA, different amount of powered samples and the final $2 \mathrm{mM}$ ascorbic acid. The reaction mixtures were incubated for $1 \mathrm{hr}$. at $37^{\circ} \mathrm{C}$, after which 17 $\mathrm{mM}$ trichloro acetic acid (TCA) was added. The mixture was then boiled for 15 minutes, ice cooled and measured for absorbance at $532 \mathrm{~nm}$. Distilled water in lieu of extract was utilized as blank and the sample solution without added deoxyribose was used as a sample blank.

\section{c. Superoxide anion radical scavenging activity}

Superoxide anion scavenging activity was measured based on the method described by Robak and Gryglewski (1988). Superoxide radicals were generated in a PMS-NADH system via the oxidation of NADH and then assayed by the reduction of nitro blue tetrazolium (NBT). The superoxide radicals were generated in reaction mixture containing sodium phosphate buffer (100 mM, pH 7.4) containing $150 \mu \mathrm{M}$ NBT, $468 \mu \mathrm{M}$ NADH solution in sodium phosphate buffer and different concentrations of methanolic extracts of the samples. To this $60 \mu \mathrm{M}$ phenozine metho sulphite (PMS) solution was added. The reaction mixture was incubated for 5 minutes at $25^{\circ} \mathrm{C}$ and the absorbance was measured at $560 \mathrm{~nm}$.

d. Reducing power assay for 20 minutes. The O.D was taken at $700 \mathrm{~nm}$ and the blank

The reducing power assay was carried out by the method of Oyaizu (1986). Different concentrations of the methanolic extracts of the samples were taken in different test tubes. To the test tubes $2.5 \mathrm{ml}$ of sodium phosphate buffer and 1 per cent potassium ferric cyanide solution was added. These contents were mixed well and were incubated at $50^{\circ} \mathrm{C}$ for 20 minutes. After incubation 10 per cent TCS was added and were kept for centrifugation at $3000 \mathrm{rpm}$ for 10 was prepared by adding every other solution but without extract (sample) and ferric chloride ( 0.1 per cent) and the control was prepared by adding all other solutions but without extract.

\section{e. Total antioxidant activity}

For total antioxidant assay various concentrations of methanolic extracts of the rice were mixed with $1 \mathrm{ml}$ of the reagent solution (0.6 $\mathrm{M}$ sulphuric acid, $28 \mathrm{mM}$ sodium phosphate and $4 \mathrm{mM}$ ammonium molybdate). The reaction mixture was incubated in a water bath at $95^{\circ} \mathrm{C}$ for 90 minutes. After cooling to room temperature, the absorbance was measured at $695 \mathrm{~nm}$ (Preito et al., 1999).

f. Total phenols

Method suggested by Sadasivam and Manickam (1992) were used for estimating total phenols.

g. Zinc

A.O.A.C. (1990) methods were used for estimating zinc (Zn).

\section{h. Selenium $(\mathrm{Se})$}

The samples were powdered and digested in concentrated nitric acid in a microwave digester. Se content of the digest was estimated in AAS using hydride vapour generator.

\section{RESULTS AND DISCUSSION}

\section{a) DPPH radical scavenging activity}

$\mathrm{DPPH}$ is a free radical compound which has been extensively used to determine the free radical scavenging is considered good invitro model widely used to assess antioxidant efficacy within a very short time (Marxen et al., 2007; Lee et al., 2007).

Results of the present study indicated that Njavara yellow variety had shown highest DPPH scavenging activity compared to the other two rice varieties, with an $\mathrm{IC}_{50}$ value 
of $31.52 \mu \mathrm{g} / \mathrm{ml}$ for $\mathrm{NY}, 33.73 \mu \mathrm{g} / \mathrm{ml}$ for $\mathrm{NB}$ and 52.39 $\mu \mathrm{g} / \mathrm{ml}$ for Hraswa control variety (Fig. 1). $\mathrm{IC}_{50}$ value of positive control ascorbate was $3.90 \mu \mathrm{g} / \mathrm{ml}$. This is in tune with the results of Smitha et al. (2012) who found that Njavara black variety (bran) was having higher scavenging activity with 2, 2-diphenyl-1-picryl hydrazyl radical with an $\mathrm{IC}_{50}$ value of $84.66 \mu \mathrm{g} / \mathrm{ml}$.

A study on Njavara rice bran by Rao et al. (2010) revealed that Njavara had the highest DPPH scavenging activity among the four tested rice varieties viz. Njavara $\left(\mathrm{IC}_{50}\right.$ value of $30.85 \mu \mathrm{g} / \mathrm{ml}$ ), Vasumathi ( IC $_{50}$ value of $87.72 \mu \mathrm{g} / \mathrm{ml}$ ), Yamini $\left(\mathrm{IC}_{50}\right.$ value of $70.58 \mu \mathrm{g} / \mathrm{ml}$ ) and Jyothi $\left(\mathrm{IC}_{50}\right.$ value of $48.88 \mu \mathrm{g} / \mathrm{ml}$ ).

\section{b) Hydroxyl radical scavenging activity}

The hydroxyl radical is a very reactive oxygen species (ROS) with a short half-life, and is considered to be responsible for much of the biological damage inherent to free radical pathology (Hochestein and Atallah, 2008). This radical has the ability to cause strand breakage in DNA, which is a contributing factor to carcinogenesis, mutagenesis, and cytotoxicity. Moreover, hydroxyl radicals have been identified as one of the rapid initiators of the lipid peroxidation process, via the abstraction of hydrogen atoms from unsaturated fatty acids (Kappus, 2003).

In the present investigation, NY showed the highest hydroxyl radical scavenging activity with an $\mathrm{IC}_{50}$ value of $46.00 \mu \mathrm{g} / \mathrm{ml}$ ) followed by NB ( $\mathrm{IC}_{50}$ value of $55.68 \mu \mathrm{g} / \mathrm{ml}$ ) and Hraswa (control variety) had $\mathrm{IC}_{50}$ value of $60.78 \mu \mathrm{g} / \mathrm{ml}$ (Fig. 2). Ascorbic acid was used as reference compound and its $\mathrm{IC}_{50}$ value was $3.90 \mu \mathrm{g} / \mathrm{ml}$. Similar findings were reported by Smitha (2012).

\section{c) Super oxide anion-radical scavenging activity}

Over-production of superoxide anion radical has long been known as the starting point of ROS/RNS accumulation in cells, contributing to redox imbalance and other associated deleterious physiological consequences (Pervaiz and Clement, 2007).

Results of the present study revealed that among the three rice varieties $\mathrm{NB}$ showed the highest value for superoxide activity. The $\mathrm{IC}_{50}$ value of $\mathrm{NB}$ was $48.78 \mu \mathrm{g} / \mathrm{ml}$, whereas $\mathrm{NY}$ has an $\mathrm{IC}_{50}$ value of $55.43 \mu \mathrm{g} / \mathrm{ml}$ and Hraswa control variety had an $\mathrm{IC}_{50}$ value of $60 \mu \mathrm{g} / \mathrm{ml}$ (Fig. 3). $\mathrm{IC}_{50}$ value of control was $3.90 \mu \mathrm{g} / \mathrm{ml}$. Similar findings were reported by Smitha et al. (2012).

\section{d) Reducing power assay}

The reducing ability of a compound generally depends on the presence of reductants which exhibited antioxidative potential to break the free radical chain reaction by donating hydrogen atom (Venkataswamy et al., 2010).
Present investigation showed that as the concentration increased from $100 \mu \mathrm{g}$ to $500 \mu \mathrm{g} / 100 \mathrm{ml}$, the reducing power of all the rice varieties increased and the highest reducing power was shown by NB (Fig. 4).

A study on the antioxidant and anti-proliferative activities of methanolic extracts from Njavara rice bran extracts increased with the increasing concentration, which is in line with the present investigation and Njavara rice bran extracts showed the highest reducing power when compared to other rice varieties (Rao et al., 2010).

\section{e) Total antioxidant activity}

According to Evans and Miller (2004) total antioxidant activity is based on the antioxidant potential of pure compounds to quench and inhibit the formation of a coloured radical cation produced by the action of the reagent solution.

In the present study, the rice samples showed an increase in the total antioxidant activity with the increase in concentration from $20 \mu \mathrm{g}$ to $100 \mu \mathrm{g} / 100 \mathrm{ml}$. Even though all the rice varieties have shown an increase in the total antioxidant with increasing concentration, but among the three rice varieties, NY had shown the highest total antioxidant activity (Fig. 5).

Rao et al. (2010) reported similar findings that total antioxidant activity of Njavara rice bran extracts increased with increase in concentration and also highest among the different varieties studied.

f) Total phenol content

Table.1. Total phenol content of the selected rice varieties

\begin{tabular}{c|c}
\hline Variety & Total phenol content (mg) \\
\hline NB & 0.41 \\
NY & 0.29 \\
Hraswa(Control) & 0.32 \\
\hline F- values & $17.55^{* *}$ \\
\hline CD values & 0.079 \\
\hline
\end{tabular}

** Significant at $1 \%$ level

Significant at $5 \%$ level

Polyphenols are major plant compounds with potential antioxidant activity. This activity is believed to be mainly due to their redox properties, which play an important role in absorbing and neutralizing free radicals, quenching singlet and triplet oxygen or decomposing peroxides (Petti and Scully, 2009; Han et al., 2004).

Present study revealed that among the three rice varieties NB had the highest total phenol content $(0.41 \mathrm{mg} / 100 \mathrm{~g}$ of rice). Rao and co-workers (2010) in Njavara rice bran reported that total phenolic content of Njavara is significantly high when compared to Jyoti, Yamini and Vasumathi. 
g) Zinc and Selenium content

Table.2: Zinc and Selenium content of selected rice varieties

\begin{tabular}{|c|c|c|}
\hline Variety & Zn $(\mathbf{m g} / \mathbf{L})$ & Se $(\boldsymbol{\mu g} / \mathbf{m l})$ \\
\hline NB & 0.883 & 4.731 \\
NY & 0.899 & 2.217 \\
Hraswa(Control) & 0.902 & 7.410 \\
\hline
\end{tabular}

In the case of NB and NY, Zn content was slightly higher in NY than NB. Similar results were reported by Hossam et al. (2010).
Selenium is a component of the unusual amino acids selenocysteine and selenomethionine. In humans, $\mathrm{Se}$ is a trace element nutrient that functions as co-factor for reaction of antioxidant enzymes, such as glutathione peroxidases and certain forms of thioredoxin reductase found in animals and in some plants (ipi.oregonstate.edu). The present study revealed that control variety Hraswa had the highest Se content $(7.41 \mu \mathrm{g} / \mathrm{ml})$. According to Morris and Levander (1990) polished rice had a Se content of 0.334 $\mu \mathrm{g} / \mathrm{gm}$ of rice.

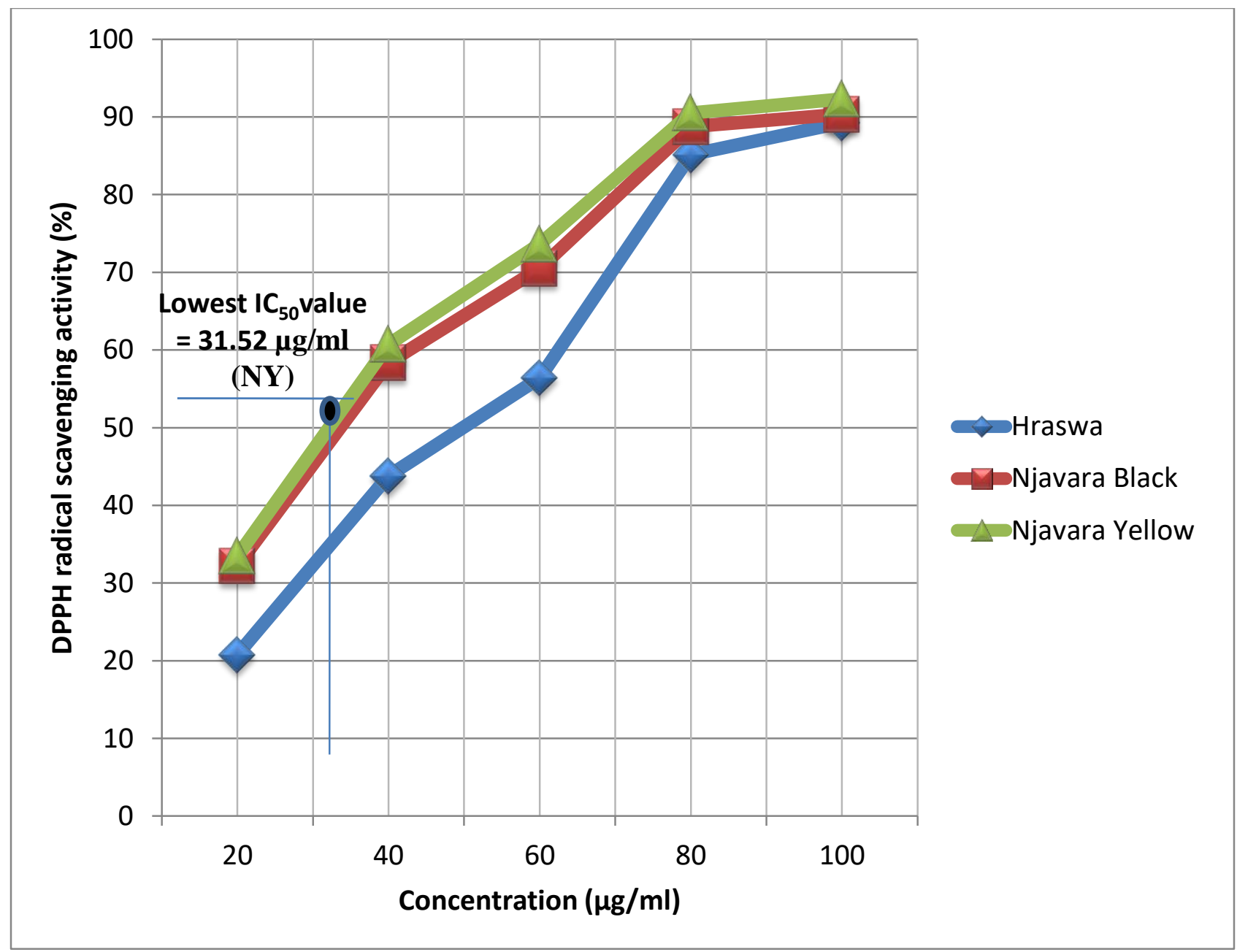

Fig. 1: DPPH radical scavenging activity of selected rice varieties 


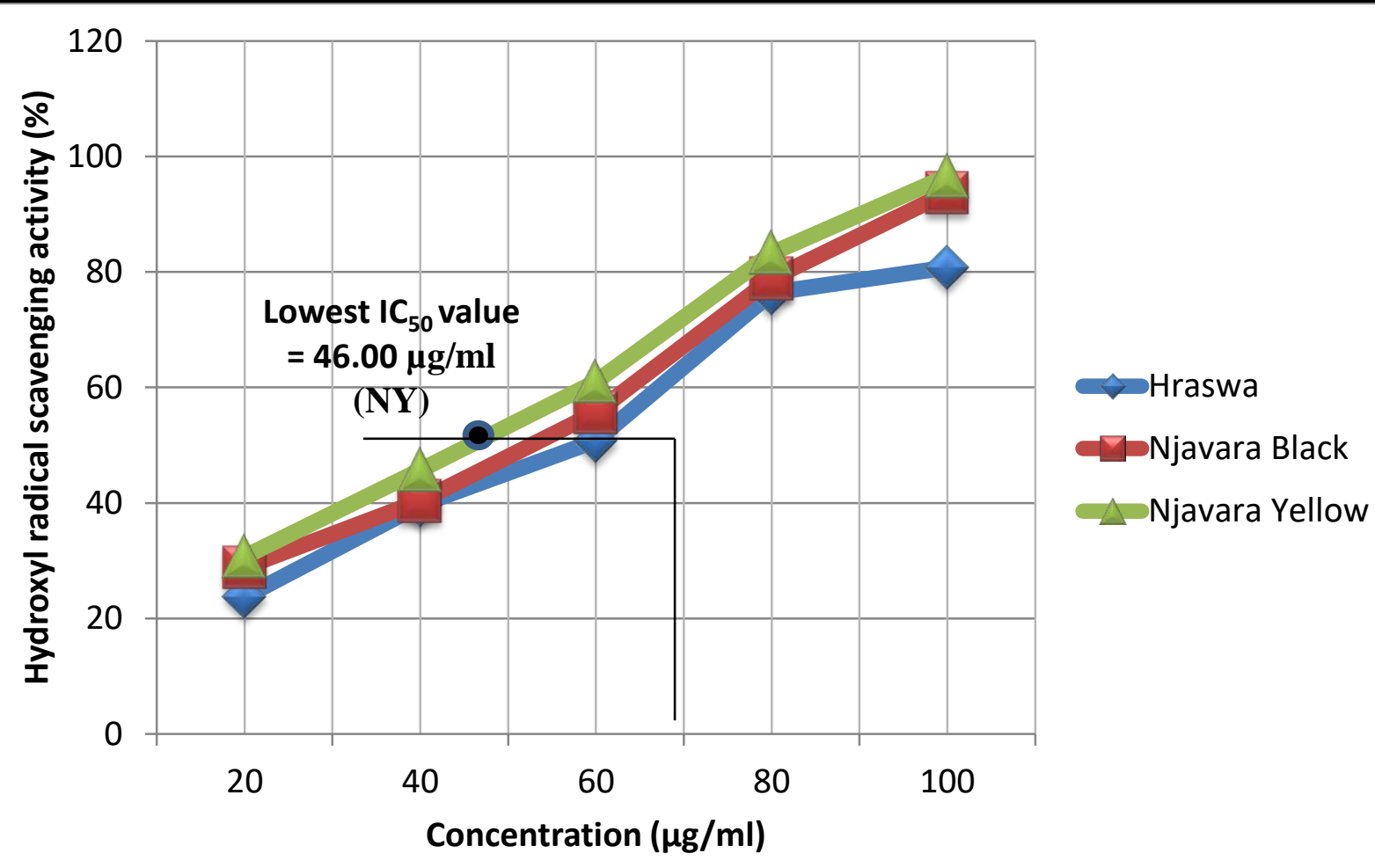

Fig.2: Hydroxyl radical scavenging activity of selected rice varieties

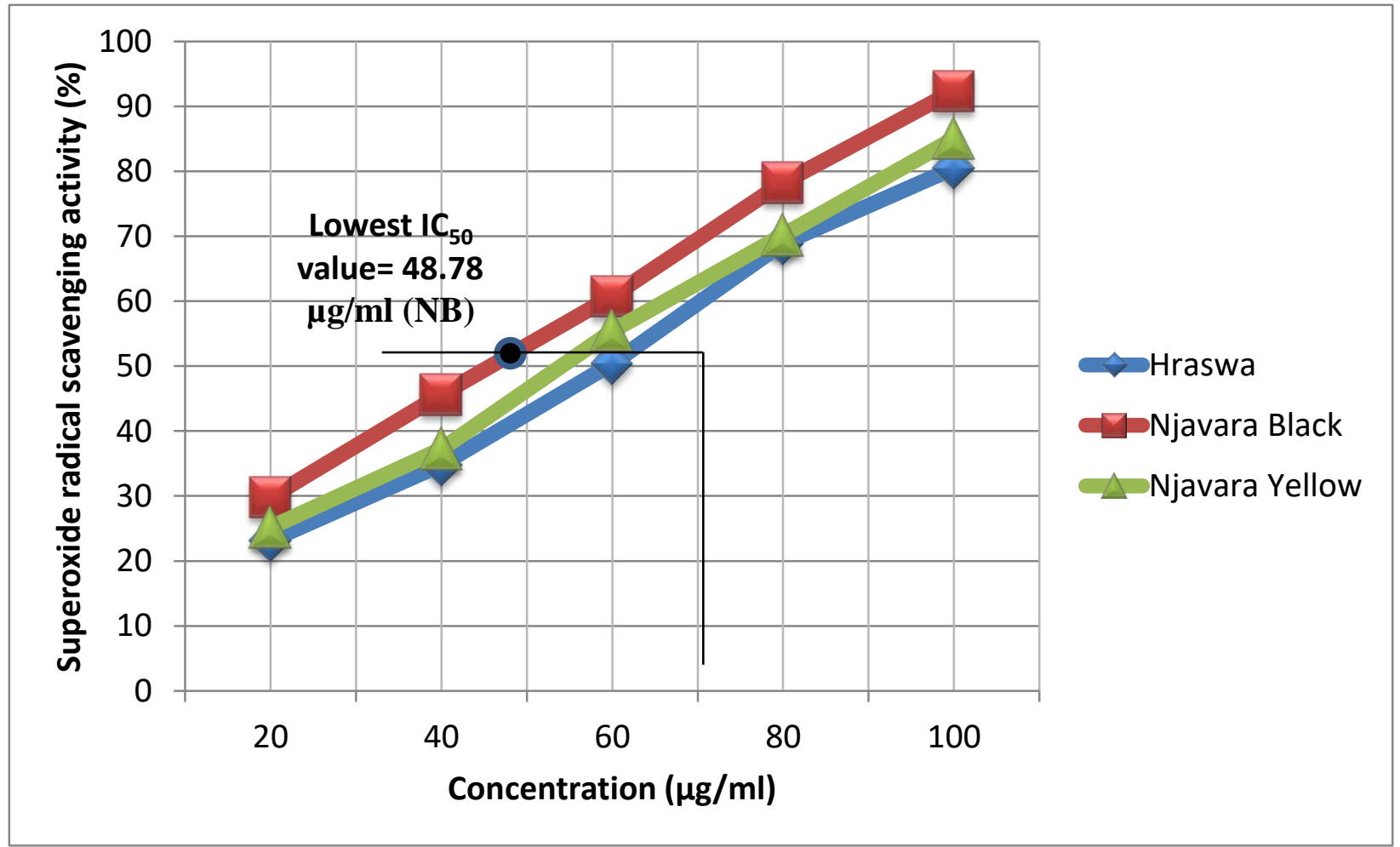

Fig. 3. Superoxide radical scavenging activity of selected rice varieties 


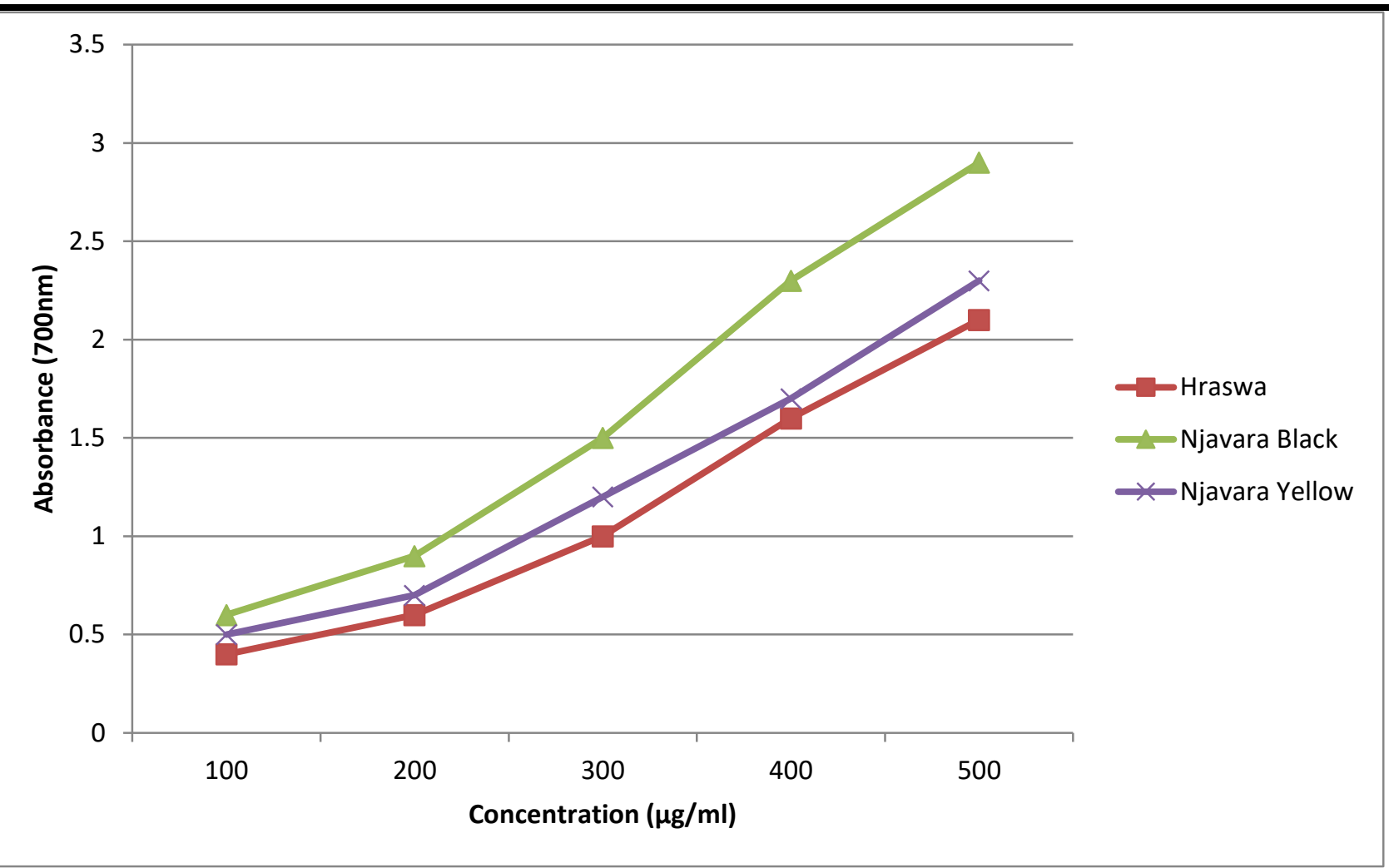

Fig.4: Reducing power assay of selected rice varieties

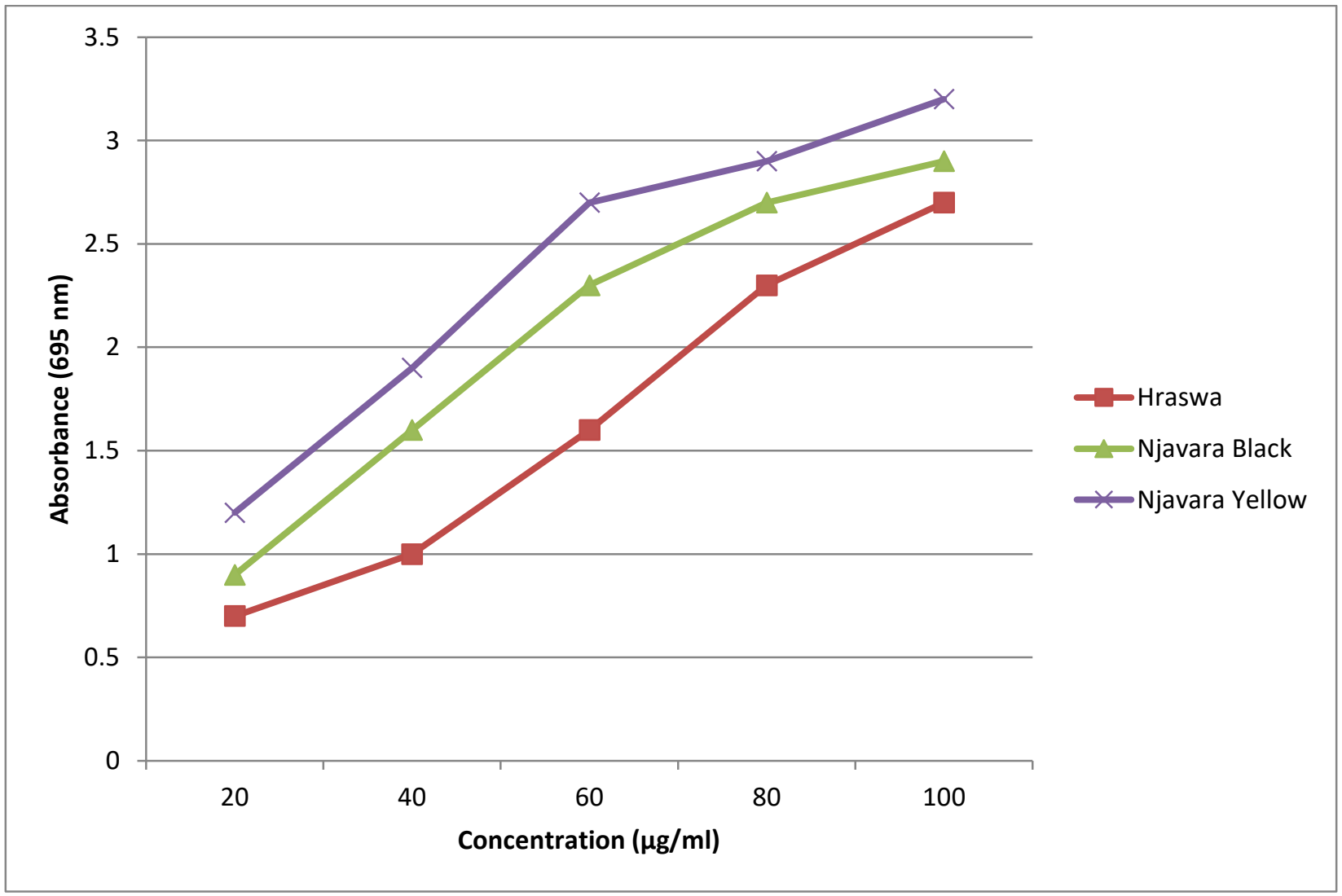

Fig. 5: Total antioxidant activity of selected rice varieties 


\section{CONCLUSION}

A study was conducted to assess the antioxidant activity of medicinal rice (Oryza Sativa L.) cv. Njavara and the results revealed that among the three rice varieties selected NY had the highest DPPH activity and hydroxyl radical scavenging activity with an with an $\mathrm{IC}_{50}$ value of $31.62 \mu \mathrm{g} / \mathrm{ml}$. and 46 $\mu \mathrm{g} / \mathrm{ml}$ respectively. NB ( $\mathrm{IC}_{50}$ value of $48.78 \mu \mathrm{g} / \mathrm{ml}$ ) showed the highest superoxide anion radical activity and reducing power. Highest total antioxidant activity was shown by NY. Among the three rice varieties, NB had the highest total phenol content. And regarding the Se content control variety Hraswa had the highest value.

\section{REFERENCES}

[1] A.O.A.C. 1990.Official Methods of Analysis: Fifteenth edition. Association of Official Analytical Chemists, Inc., Arlington, VA, 318 p.

[2] Barros, L., Ferreira, M.J., Queiros, B., Ferreira, I.C.F.R . and Baptista, P. 2007. Total phenols, ascorbic acid, $\beta$-carotene and lycopene in Portuguese wild edible mushrooms and their antioxidant activities. Food Chem., 103: 413 - 420.

[3] Blois, M.S. 1958. Antioxidant determinations by the use of stable free radicals. Nature., 81:1199-2000.

[4] Deepa, G., Venkatachalam, L., Bhagyalakshmi, N., Shashidhar, H.E., Singh, V. and Naidu, K.A. 2009. Physiochemical and genetic analysis of an endemic rice variety, Njavara (Oryza sativa L.), in comparison to two popular South Indian cultivars, Jyothi (PTB 39) and IR 64. J. Agric. Food Chem., 57(24): 1147611483.

[5] Evans, R. and Miller, N.I. 2004. Total antooxidanr status in plasma and body fluids. Methos Enzymol. 234: 279-293.

[6] Geethakutty, P.S., Nair, S. and Pratheesh, V.S. 2004. Medicinal Rice and Traditional Knowledge of Women. Compendium of papers. Science - Society Interface on Medicinal and Aromatic Rices 20-21 August 2004 organised by M.S. Swaminathan Research Foundation, Chennai and Kerala Agricultural University, Thrissur. $123 \mathrm{p}$.

[7] Halliwell, B., Gutteridge, J.M.C. and Aruoma, O.I. 1987. The deoxyribose method a simple assays fro determination of rate constants for reaction of hydroxyl radicals. Anal. Biochem., 165: 215-219.

[8] Han, S.J., Ryu, S.N. and Kang, S.S. 2004. A new 2arylbenzofuran with antioxidant activity from the black colored rice (Oryza sativa L.) bran. Chem Pharm Bull , 52:1365-1366.
[9] Hochestein, P. and Atallah, A.S. 2008. The nature of oxidants and antioxidant systems in the inhibition of mutation and cancer. Mutat Res., 202: 363-375.

[10] Hossam, S.E.B., Shallan, M.A., Mona, A.M. and Amera, T.M. 2010. Chemical evaluation of pregerminated brown rice and whole grain rice bread. J. Environ. Agric. and Food. Chem., (3): 958-971.

[11] Kappus, H. 2003. Lipid peroxidation-mechanism and biological relevance. In Free radical and food additives. Aruoma, O.I., Halliwell, B., eds. Taylor and Francis, London. 59-75 p.

[12] Lai, P. Li, K.Y., Lu,S. and Chen,H.H. 2009. Phytochemicals and antioxidant properties of solvent extracts from Japonica rice bran. Food Chem., 117:538-544.

[13]Lee, Y.R., Woo, K.S., Kim, K.J., Son, J.R. and Jeong, H.S. 2007. Antioxidant activities of ethanol extracts from germinated specialty rough rice. Food Sci. Biotech., 16:765-770.

[14] Marxen, K., Vanselow, KH., Lippemeier, S., Hintze, R., Ruser, A. and Hansen, U.P. 2007. Determination of DPPH radical oxidation caused by methanolic extracts of some micro algal species by linear regression analysis of spectrophotometric measurements. Sensors., 2080-2095.

[15] Morris, V.C. and Levander, O.A. 1990. Selenium content of foods. J. Nutr., 100: 1383-1388.

[16] Oyaizu, M. 1986. Studies on products of browning reaction: antioxidant activities of products of browning reaction prepared from glucosamine. Jpn. J. Nutr. 44: 307-315.

[17] Preito, P., Pineda, M. and Anguilar, M. 1999. Spectrophotometric quantification of antioxidant capacity through the formation of a phosphomolybdenum complex: specific application to the determination of vitamin E. Anal. Biochem. 269:337-341.

[18]Pervaiz, S. and Clement, M. 2007. Superoxide anion: oncogenic reactive oxygen species? Int J Biochem Cell Biol., 39: 1297-1304.

[19] Petti, S. and Scully, C. 2009. Polyphenols, oral health and disease: a review. J. Dentistry., 37:413-423.

[20] Raghuramalu, N., Madhavan Nair, K. and Kalyana, S. 1983. Food analysis. A manual of Laboratory Techniques. National Institute of Nutrition, Indian Council of Medical Research, JamaiOsmania, Hyderabad, p 38.

[21] Rao, A.S.V.C., Reddy, S.G., Babu, P.P. and Reddy, A.R. 2010. Antioxidant and antiproliferative activities 
of methanolic extracts from Njavara rice bran. BMC

Complementary and Alternative Medicine., 10: (4) 1-

9.

[22] Robak, J. and Gryglewski, I.R.2001.Flavonoids are scavengers of superoxide anions. Biochem. Pharmacol., .37: 837-841.

[23] Robards, K., Prenzler P.D., Tucker, G. Swatsitang, P. and Glover, W. 1999. Phenolic compounds and their role in oxidative processes in fruits. Food. Chem., 66(4): 401-436.

[24] Sadasivam, S. and Manikam, A. 1992. Biochemical methods for Agricultural Sciences Wiley Eastern Limited and Tamil Nadu Agricultural University Publication, Coimbatore, 11-20 p.

[25] Singh, R., Singh, S., Kumar, S. and Arora, S. 2007. Studies on antioxidant potential of methanol extract/fractions of Acacia auriculiformis, A. Cunn. Food Chem., 103: 505-515

[26] Smitha, M., Parvathy,R., Shalini,V., Mohanan,R., Helen,A. and Jayalekshmy, A. 2012. Chemical indices, antioxidant activity and anti-inflammatory effect of extracts of the medicinal rice "Njavara" And Staple Varieties: A Comparative Study. J. Food. Biochem., doi: 10.1111/j.1745-4514.2011.00646.x

[27] Sulochana, S. and Bakiyalakshmi S. V. 2011. Effect of neutraceutical dosa on antimicrobial activity. Inter. J. Envt. Sciences., 1 (5): 727-735.

[28] Venkataswamy, R., Mubarak, M.H. and Doss, A. 2010. Antioxidant activity, phenol and flavonoid contents of Alangium Salicifolium wang stem bark. Indian. J. Nutr. Diet, 47:113-117. 